\title{
THE DIMENSIONS OF SOCIAL ENTREPRENEURSHIP
}

\section{Abstract}

The objective of this study was to construct the dimensions of social entrepreneurship by a grounded research approach. The type of research is grounded research with a qualitative approach. Data analysis is done by coding techniques. This research was conducted in Papua Province, Indonesia. The results founded that the dimensions of social entrepreneurship based on calling for conscience, humanity, spirituality, trustworthiness, and social learning to help others around them and what they see. Moreover, the dimensions of social entrepreneurship contribute to HRD that shape the characteristics of individuals who have a greater sense of empathy, social intelligence, accountability, creativity, and innovation.

Keywords: Social entrepreneurship, human resource development, social entrepreneur.

\footnotetext{
* Doctoral Candidate, Postgraduate School, Airlangga University, Surabaya, Indonesia, email: irawanpopaz@gmail.com ORCID: 0000-0003-2932-3834

${ }^{* *}$ Professor, Faculty of Psychology, Personality and Social Psychology Department, Airlangga University, Surabaya, Indonesia, email: suryanto@psikologi.unair.ac.id ORCID: 0000-0002-5368-2303

${ }^{* * *}$ Professor, Faculty of Social and Political Science, Airlangga University, Surabaya, Indonesia, email: mustainls@fisip.unair.ac.id
} ORCID: 0000-0002-6522-7041 


\section{INTRODUCTION}

Discussing the theory and practice of social entrepreneurship related with discussing creative ways in which social entrepreneurs solve social problems that place more emphasis on problems that other theories cannot overcome, (Zahra and Wright, 2016). Social entrepreneurship is a process that aims at the creation of social change and the development of a social mission that is driven by social enterprises. Mahto and Mcdowell (2018) state that the motivation of social entrepreneurs is more about achieving social goals. Satisfaction for social entrepreneurs is a feeling of great pleasure and happiness when they can, together with their stakeholders, solve social problems that occur. Furthermore, Prasziker and Nowak (2012) state that there are several types of people who get extraordinary satisfaction and succeed in changing the world even though sometimes they achieve it in unusual ways. Such people are very rare and have unique characters. Sometimes we are not aware of their existence, but when we see what they are doing and their achievements, we will realize that they are great people. The question is, if they are groups or individuals who have different characteristics, what motivates them to do social activities? What also distinguishes them from other entrepreneurs? These questions will encourage interest in identifying entrepreneurial dimensions of social entrepreneurs. For this reason, this research was conducted.

Social entrepreneurship still continues to be an interesting field of research. This is caused by the differences in contexts, actors, and phenomena in each of their existence in a certain place. The dimensions of social entrepreneurship, which revealed by previous researches by Dees and Anderson, 2010; Bouchard, 2012; Biggeri, Testi, and Bellucci, 2018 more focus on: (1) Social Missions, (2) Social Change, (3) Action, (4) Innovation, (5) Accountability, (6) Adaptation, and (7) Learning, have become a reference for research on social entrepreneurship. Other research conducted by ReyMartí (2016) reveals dimensions that focus on: (1) Social awareness, (2) Social Business, and (3) Social Responsibility. The disclosures of these dimensions indicate that the concept of social entrepreneurship is still changing and developing. Social entrepreneurship is only a field of science that is still seeking self-definition through basic practice and research with the aim of exploring and developing concepts (Nicholls, 2008). We agree with Nicholls (2008) that the concept of social entrepreneurship will certainly continue to develop in line with the phenomenon that continues to change with the different contexts and characteristics of groups or individuals. We are very enthusiastic about doing this research, with the hope that these findings can become a reference for further researchers, especially about the concept of social entrepreneurship that is related to the development of human resources for social entrepreneurs themselves.

The findings of the research on the dimensions of social entrepreneurship in the emic perspective that we have done basically are not much different from the definitions and dimensions revealed by previous studies by Kibler, 2015; Aquino, Lück, and Schänzel et al.,2018. However, we find the most powerful dimensions felt and conveyed by social entrepreneurs in the field, namely spirituality and social learning. These two dimensions are the most important part of social entrepreneurs in carrying out their activities so far.

\section{METHOD}

\subsection{Types of Research}

The type of research is grounded research with a qualitative approach. In the beginning, it was explained that this study constructs the dimensions of social entrepreneurship from field data. This research emphasizes the meaning, context and perspective of emics, the research process is more in the form of a cycle than a linear one. Data collection and data analysis is done simultaneously so that it is more concerned with depth than the breadth of the research area. In this study, in-depth 
observations and interviews were very important in the process of data collection and the researcher was involved as the main instrument. According to Straussand Glaser (2009) two important points in the decision on this method are, first, that testing becomes more rigorous than before (although not necessarily the most rigorous method); and, second, that a more rigorous approach is compatible with the research situation to produce the most reliable findings. Following Strauss, then to know and explain: how social entrepreneurship is owned by social entrepreneurs; what are the implications of social entrepreneurship on the development of human resources; and how to model social entrepreneurship in the development of human resources, we use a grounded method approach. This thinking is based on the belief that whatever is patterned as a regularity in the habits of everyday social entrepreneurs is certainly inseparable from the framework of meaning constructed in their thinking (subjectivity) as an actor. However, the subjective framework of meaning is certainly part of the social framework that institutionalizes and encompasses them. Therefore, our efforts to understand and interpret social entrepreneurship need to begin with the meaning and interpretation of social entrepreneurship actors, because they are agents who experience and explore the real problems. The experience and knowledge they have is the essence of this research which eventually becomes a concept that is built from an emic perspective.

\subsection{Location and Research Subject}

This research was conducted in Papua Province, Indonesia. This location was chosen because there were many activists, volunteers and social entrepreneurs who practiced in this area. While the research subjects in this study were social entrepreneurs as informants as many as 10 people who have been relatively long-time social entrepreneurs.

\subsection{Informant Selection Techniques}

In this study, informants must have experience about actions, situations and conditions that are in accordance with the research background. In addition, informants must be willing, without coercion, to be part of the research. The technique of determining informants in this study was purposive sampling which determined the criteria of informants according to the needs of the study. To obtain data in accordance with the purpose of this study, the criteria for determining informants are social entrepreneurs. The criteria for informants in this study are shown in the following table:

Table 1: Criteria for informants

\begin{tabular}{llccc}
\hline Informants & Work & Gender & Ages & Experience \\
\hline Agus Purnomo & Social Entrepreneur & Male & 35 & 10 \\
MaulidaGhoirulThoriqoh & Social Entrepreneur & Female & 53 & 6 \\
TaufikOktavianto & Social Entrepreneur & Male & 37 & 3 \\
Zainal Effendi & Social Entrepreneur & Male & 32 & 2 \\
TiknoDwiRiski & Social Entrepreneur & Male & 48 & 4 \\
RiskaKusumawati & Social Entrepreneur & Female & 28 & 2 \\
PartoMulyono & Social Entrepreneur & Male & 30 & 5 \\
AssalamSuaji & Social Entrepreneur & Male & 35 & 5 \\
Amalia Putri Rahmawati & Social Entrepreneur & Female & 28 & 4 \\
RusdiSailendra & Social Entrepreneur & Male & 53 & 10 \\
\hline
\end{tabular}




\subsection{Data Sources}

This study utilizes two data sources; first, the primary data obtained through interviews are in the form of statements, subjective perceptions and feelings of social entrepreneurs. The second source is secondary data in the form of documents or data generated from parties outside the informant, which are used as support in the research.

\subsection{Research Techniques}

Lincoln and Guba qtd. in Kokko (2018) state that qualitative research relies on truth-worthiness. Furthermore, they put forward the concept of credibility, transferability, dependability, and confirmation. In this study, to meet the standards of credibility, several techniques were carried out. First, we settled in the field (at the study site) in a fairly long period of time, which is eighteen months so that the level of appreciation for entrepreneurs can be more assured. Second, we carried out participant observation. Third, triangulation. Fourth, conducted peer debriefing. Fifth, conducted a negative case analysis. Sixth, we conducted member checks to check the suitability of the results of research by agents as entrepreneurs.

\subsection{Data Analysis}

Data analysis is done by coding techniques through the process of identifying, integrating and filtering all categories related to core categories alternately (cycles) with an open coding process to develop conceptualizations (Strauss, 2009).

\section{RESULTS AND DISCUSSION}

\subsection{Social Entrepreneurship Dimensions}

\section{Call of conscience and sense of humanity}

The calling of conscience and a sense of humanity is one of the reasons entrepreneurs carry out social activities and business so far. Feeling of wanting to help when seeing other people need help, makes them unable to remain silent to not act and provide solutions to problems faced by others. The altruistic and humanitarian actions they carry out sometimes harm themselves and cause injustice for others who experience the same problems as the people they help. For example, they are faced with a condition where there are two people having problems and needing their help, but they have to choose one of them which causes a sense of injustice to others.

\section{Trustworthiness}

Trustworthiness in social entrepreneurship is the most important attitude. It is the most valuable capital that serves to maintain positive ties between them and the people they help or with other people who contribute to their activities and social endeavours (Gereke, Schaub, and Baldassarri, 2018). For this reason, trustworthiness in their minds is like a weapon capable of destroying a sense of selfishness, apathy, and pessimism so that they will stay connected with fellow networks of social entrepreneurs, donors, and clients with the principle of mutual trust that will facilitate all the actions they take (Tang, Moro, Sozzo, and Li, 2019).

\section{Spirituality}

Spirituality is the dimension most often expressed by social entrepreneurs when interviewed. Spirituality is the most powerful dimension encouraging them to become a social entrepreneur to help 
others with the aim of doing good and getting closer to God (Tiwari, and Elsdörfer, 2018). Furthermore, the value of spirituality is able to make them become more patient in facing obstacles when carrying out their social missions, they believe in God's help when they face difficulties, and all will be easy in their beliefs.

\section{Social Learning}

Very few social entrepreneurs get formal education and training. Even though they attend training, it is only for the purposes of certification or the legitimacy of their existence. When informants first became social entrepreneurs, they did not have education or expertise in the field of entrepreneurship. Most of them are social workers who only carry out social missions to help others. The experience they get during carrying out social missions is a valuable lesson for them in facing the obstacles and problems they find. They can learn from cases that have been resolved and learn from the social networks they have, to share experiences with conditions or cases that have been faced and resolved. Social learning can make social entrepreneurs understand and empathize with the surrounding conditions through the learning process of their experiences, social environment and social networks (Coudel: 2017, Kraker:et al., 2018).

Social entrepreneurship in the emic perspective is not just about combining economic and social principles. Furthermore, in their view and world, social entrepreneurs, the call of conscience, a sense of humanity, maintaining the trust of others, spirituality and social learning are dimensions that can complement each other and enhance one's spirit of social entrepreneurship. In an emic perspective, social entrepreneurship is not just a business activity aimed at social purposes only. In their world, social entrepreneurship is all forms of business to make other people interested and involved both directly and indirectly in social actions through the call of conscience, a sense of humanity, a trustworthy personality and spirituality and also desire to learn by utilizing their social networks, so that other people are interested in participating in entrusting their charity goals both morally and materially.

According to their beliefs, all human beings have a sense of humanity, trustworthiness and spirituality, but not all humans have the calling of conscience and opportunities to learn socially as they do. For this reason, they are present to carry out social missions and provide a "forum" for others to show their social dimensions such as the calling of conscience, a sense of humanity, trust, spirituality and social learning through the activities they do. We see this finding very interesting to be examined more broadly, so that it can reveal the secrets behind social entrepreneurship.

\subsection{The Implications of Social Entrepreneurship in Human Resource Development}

Research on the implications of entrepreneurship on HRD such as motivation, innovation and creativity has been widely carried out byMahto and Mcdowell; QER: 2018, Pagano, Petrucci, and Bocconcelli, 2018; Jensen, 2014. However, in this study, we explain how our findings on the social dimension of entrepreneurship have impacts on HRD. To start we show the following model; 
Figure 1: The Implications of Social Entrepreneurship in Human Resource Development

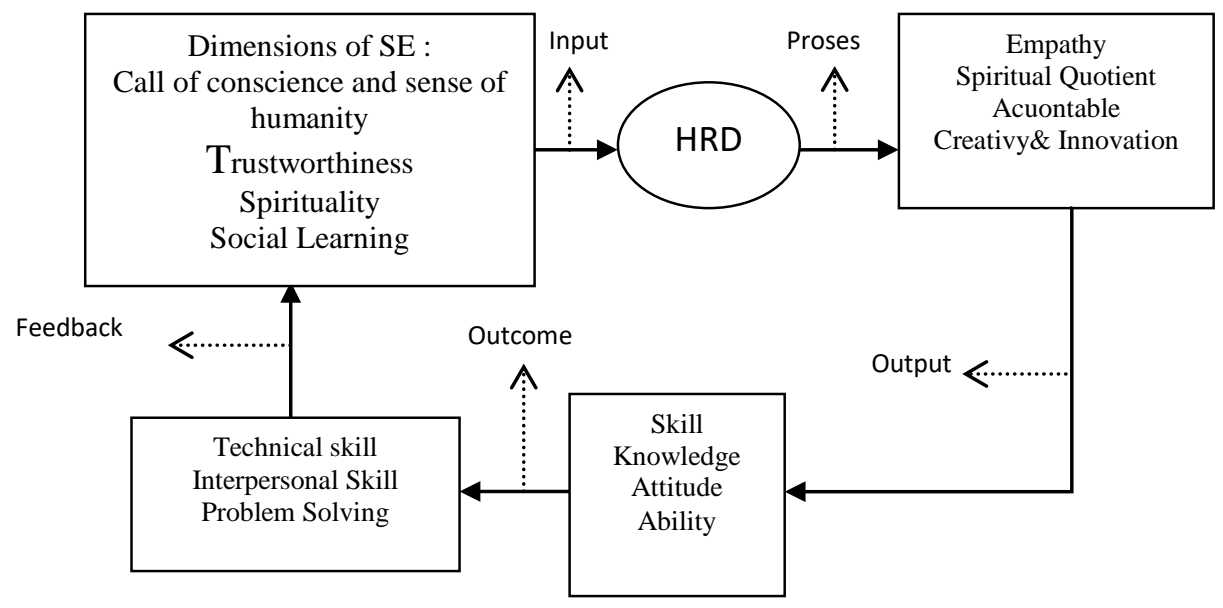

The dimensions of social entrepreneurship have implications for HRD by means of; First, someone who has a call of conscience and a sense of humanity will have a personality with high empathy (Esther, Enrique, and Mendoza, et al., 2018). This empathy would encourage someone to help others in need, in this case it was found that social entrepreneurs help each other solve problems because they are driven by the same feelings, emotions, goals, and desires to improve conditions so that their affective and cognitive responses emerge to be involved in solving problems or other people's work. Second, spirituality gives confidence to social entrepreneurs that by helping others they will get the same reward from God. In the context of HRD, this belief can increase the spiritual intelligence, and the care for others and the natural surroundings. So that people who have good spiritual intelligence will be able to manage, control and direct the organization to positive goals. (Series and Science, 2018). Furthermore, empathy and spiritual intelligence will have an impact on a person's attitude and behaviour at work. People who have good empathy and spiritual intelligence will be more easily be accepted in their environment and easy to collaborate in organizations (Schutte et al., 2017).

This research proves that entrepreneurs who have a more spiritual attitude are able to approach their clients easily and help them solve their problems. This is different from entrepreneurs who have fewer spiritual attitudes that prove to be a little difficult to approach clients who will be helped. Entrepreneurs who have spiritual attitudes and intelligence will be more trusted (Ramadani, 2017). For this reason, empathy, spiritual intelligence and attitudes will contribute to one's ability to interact with other people and colleagues, they will be good listeners when their colleagues speak and will express their opinions clearly and wisely when speaking, this is called interpersonal skills (Eunson, 2016). Third, maintaining trustworthiness is very important in social entrepreneurship. Trustworthiness is basically the beliefs of others towards us so that we are considered to be able and reliable (Tang, Gereke et al., 2018). However, to run a social business is required to always be open and transparent in presenting what will be done and how the results of his actions, the accountability of a social entrepreneur is a valuable capital so that his social business will remain (Venturing, 2018). In this case, maintaining trustworthiness can increase individual accountability so that other people are increasingly interested in being involved and willing to accept risks for whatever results from the actions of trusted people. Fourth, social learning can increase creativity, innovation and knowledge of a social entrepreneur in solving problems. The character of the community, the environmental and geographical conditions of each region is certainly different, this requires them to learn from 
experiences they have had through ways and strategies that are tailored to the local context. The social networks they have are not spared from their use as learning media. Experience and social networks are like a library of the universe for social entrepreneurs who function as places for learning, seeing and listening. Knowledge is an important element that must be owned by everyone (Jacobs, 2018). However, a social entrepreneur must be able to solve the problems faced with the knowledge they have, as well as the creative ideas and innovations they create (Smith, Kistruck, and Cannatelli, 2016). Furthermore, creativity and innovation will have an impact on the problem-solving abilities they face (Hooda and Devi, 2018). This ability is the main weapon for social entrepreneurs to show their existence in the world, that they are worthy of being recognized and legally recognized (Kibler, Salmivaara, Stenholm, and Tersesen, 2018).

\section{CONCLUSION}

We find the dimensions of social entrepreneurship on the basis of calling for conscience, humanity, spirituality, trustworthiness, and social learning to help others around them and what they see. However, we also found the types of social entrepreneurs who manage businesses but do not use their business profits to support their social activities. The profit they get is used to strengthen the economic resilience of their families. This decision is made for the purpose of if they are faced with a condition that requires them to leave their families to do social activities, the family they leave behind is maintained by their economic resilience. This can provide freedom and calm for entrepreneurs during their social activities. Although sometimes there are profits that they channel to social activities, most of the profits from the business are to support the economic resilience of their families. In this condition there is certainly an exchange between economic and social needs (Madanoglu, 2018). However, social entrepreneurship is not only interpreted as a combination of economic and social principles. In the world of social entrepreneurs, social activities to get financial support from communities outside their environment do not have to go through activities that are based on economic principles such as selling products or services. According to them, the business they built prioritized social efforts such as building the trust of others through honesty, sincerity and sacrifice that they showed to others so as to create a point of interest for other people to "entrust" their donations as charity purpose. Trustworthiness, sincerity and sacrifice in their world are interpreted as "products" or "services" that have "selling" values and are invaluable with anything even not everyone has all of them. In their view, the effort to get income is a form of "social entrepreneurship" even though in practice it is not like a social business that uses economic principles; where the product or service is visible and can be valued at an appropriate price, even though the purpose is for social activities and purposes. The business of "selling themselves" (in the positive sense) that they build, puts more emphasis on the principle of trustworthiness, sincerity and the form of sacrifice for a noble cause.

The implications of social entrepreneurship on HRD are very clear. The dimensions of social entrepreneurship contribute to HRD that shape the characteristics of individuals who have a greater sense of empathy, social intelligence, accountability, creativity, and innovation. However, the characteristics of such HRD certainly have qualities that meet the elements of human resources such as skill, knowledge, attitude, and ability as an important part of HRD (Biruta, Kantane, and Dzelme, 2015). The quality of human resources like this will improve skills and expertise in the fields of technical skills, interpersonal skills, and problem-solving skills. For this reason, the results of this study will contribute to the improvement and enhancement of the quality and capacity of social entrepreneurship elsewhere. 


\section{Acknowledgements}

We thank all the informants and social entrepreneurs who have provided criticisms, suggestions, statements, and contributions to this article. The second and third authors contributed equally to the progress of this article. We thank the promoter and co-promoter for other valuable contributions and suggestions during the research and preparation of the article. We also express our gratitude to the Ministry of Technology, Research, and Higher Education of the Republic of Indonesia for awarding grants for conducting this research.

\section{REFERENCES}

Akhtar, S., Arshad, M. A., Mahmood, A., \& Ahmed, A. (2015). Spiritual Quotient and Ethical Values towards Organizational Sustainability Spiritual Quotient and Ethical Values towards Organizational Sustainability Sohail Akhtar , Dr Mohd Anuar bin Arshad , Arshad Mahmood , Adeel Ahmed , (September). https://doi.org/10.18052/www.scipress.com/ILSHS.58.1

Amini, Z., Arasti, Z., \& Bagheri, A. (2018). Identifying social entrepreneurship competencies of managers in social entrepreneurship organizations in healthcare sector. Journal of Global Entrepreneurship Research, 8(1), 19. https://doi.org/10.1186/s40497-018-0102-x

Andreoni, J., Diego, S., Harbaugh, W. T., \& Vesterlund, L. (2018). Altruism in Experiments, (September). https://doi.org/10.1057/978-1-349-95189-5

Aquino, R. S., Lück, M., \& Schänzel, H. A. (2018). A conceptual framework of tourism social entrepreneurship for sustainable community development. Journal of Hospitality and Tourism Management, 37(September), 23-32. https://doi.org/10.1016/j.jhtm.2018.09.001

Basit, S. A., Hussain, A., Nasim, S., \& Siddiqi, Z. (2015). Relationship between Interpersonal Skills , Analytical Skills and Career Relationship between Interpersonal Skills , Analytical Skills and Career Development ., (September).

Biggeri, M., Testi, E., \& Bellucci, M. (2018). Social Entrepreneurship and Social Innovation. https://doi.org/10.4324/9781351239028

Biruta, S., Kantane, I., \& Dzelme, J. (2015). Expectations by Employers on Skills , Knowledge and Attitudes of Employees, (November). https://doi.org/10.5755/j01.eis.0.9.12809

Boella, L. (2018). From Empathy to Empathies . Towards a Paradigm Change, 9(September), 1-13. https://doi.org/10.4453/rifp.2018.0001

Bouchard, M. J. (2012). Social innovation, an analytical grid for understanding the social economy: The example of the Quebec housing sector. Servive Business, (6), 47-59.

Coudel, E. (2017). Social learning for territorial development, (December).

Elsdörfer, U. (2018). Spiritual Encounter in Diversity Focussing Spiritual Counselling in Asia, (August). https://doi.org/10.13140/RG.2.2.19201.15205

Esther, D., Enrique, A., \& Mendoza, J. (2018). Levels of empathy, empathy decline and differences between genders in medical students of Cartagena (Colombia). Educación Médica, (September). https://doi.org/10.1016/j.edumed.2018.06.004

Eunson, B. (2016). Interpersonal Skills 1 (2016 - 4th ed.), 1(August 2015), 316.

Fairbairn, G. (2018). Three Problems with Empathy, (July).

Fjeld, G. P., Tvedt, S. D., \& Oltedal, H. (2018). Guro Persdotter Fjeld , Sturle Danielsen, (October). 
https://doi.org/10.1007/s13437-018-0158-z

Gereke, J., Schaub, M., \& Baldassarri, D. (2018). Ethnic diversity, poverty and social trust in Germany: Evidence from a behavioral measure of trust. PLoS ONE, 13(7), 1-15. https://doi.org/ 10.1371/journal.pone.0199834

Guilbeault, D., Becker, J., \& Centola, D. (2018). Social learning and partisan bias in the interpretation of climate trends, (September). https://doi.org/10.1073/pnas.1722664115

Haji, J., Bemby, A. B., \& Sentosa, I. (2015). The Intelligence , Emotional , Spiritual Quotients and Quality of Managers The Intelligence, Emotional , Spiritual Quotients and Quality of Managers Strictly as per the compliance and regulations of :, (January 2013).

Henderson, G. E. (2018). Indigenous Entrepreneurship and Social Entrepreneurship in Canada, (March).

Hooda, M., \& Devi, R. (2018). Problem Solving Ability: Significance for Adolescents, (August).

Jacobs, R. L. (2018). Knowledge Work and Human Resource Development, (March). https://doi.org/ $10.1177 / 1534484317704293$

Jensen, T. L. (2014). A holistic person perspective in measuring entrepreneurship education impact Social entrepreneurship education at the Humanities. International Journal of Management Education, 12(3). https://doi.org/10.1016/j.ijme.2014.07.002

Kibler, E., Salmivaara, V., Stenholm, P., \& Terjesen, S. (2018). The evaluative legitimacy of social entrepreneurship in capitalist welfare systems. Journal of World Business, 53(6), 944-957. https://doi.org/10.1016/j.jwb.2018.08.002

Kokko, S. (2018). Social entrepreneurship: creating social value when bridging holes. Social Enterprise Journal, SEJ-01-2018-0003. https://doi.org/10.1108/SEJ-01-2018-0003

Kraker, J. De. (2018). ScienceDirect Social learning for resilience in social - ecological systems. Current Opinion in Environmental Sustainability, 28(October 2017), 100-107. https://doi.org/10.1016/j.cosust.2017.09.002

Madanoglu, M. (2018). Theories of economic and social exchange in entrepreneurial partnerships: an agenda for future research. International Entrepreneurship and Management Journal, 14(3), 649-656. https://doi.org/10.1007/s11365-018-0515-6

Mahto, R. V, \& Mcdowell, W. C. (2018). Entrepreneurial motivation : a non-entrepreneur's journey to become an entrepreneur, 513-526.

Muñoz, P., \& Kibler, E. (2015). Institutional complexity and social entrepreneurship: A fuzzy-set approach. Journal of Business Research, 69(4), 1314-1318. https://doi.org/10.1016/j.jbusres.2015.10.098

Nicholls, A. (2008). Social Entrepreneurship: New Models of Sustainable Social Chane. Oxford University Press Inc.

Pagano, A., Petrucci, F., \& Bocconcelli, R. (2018). A business network perspective on unconventional entrepreneurship: A case from the cultural sector. Journal of Business Research, 92(January 2017), 455-464. https://doi.org/10.1016/j.jbusres.2018.07.012

Parilla, E. S. (2015). Skills , Knowledge and Attitudes Needed by Companies in Metro Manila, (September).

Phillips, W., Lee, H., Ghobadian, A., Regan, N. O., \& James, P. (2015). Social Innovation and Social Entrepreneurship : A Systematic Review. https://doi.org/10.1177/1059601114560063 
Prasziker, R., \& Nowak, A. (2012). Social Entrepreneurship. Theory and Practice.

Racol, N. D., \& Babe, P. (2018). Challenges for the Development of Social Entrepreneurship in Romania Challenges For The Development Of Social, (September). https://doi.org/ 10.24193/OJMNE.2018.27.08

Ramadani, V. (2017). Social entrepreneurship in the Islamic context, (February 2018). https://doi.org/ 10.1007/978-3-319-39679-8

Rey-Martí, A., Ribeiro-Soriano, D., \& Sánchez-García, J. L. (2016). Giving back to society: Job creation through social entrepreneurship. Journal of Business Research, 69(6), 2067-2072. https://doi.org/10.1016/j.jbusres.2015.12.010

Schutte, T., Tichelaar, J., Reumerman, M. O., Eekeren, R. Van, Rissmann, R., Kramers, C., ... Al, E. T. (2017). Pharmacovigilance Skills , Knowledge and Attitudes in our Future Doctors - A Nationwide Study in the Netherlands, 475-481. https://doi.org/10.1111/bcpt.12712

Series, I. O. P. C., \& Science, M. (2018). Emotional and Spiritual Quotient Approach Improve Biology Education Students 'Acceptance of Evolution Theory Emotional and Spiritual Quotient Approach Improve Biology Education Students ' Acceptance of Evolution Theory. https://doi.org/10.1088/1757-899X/335/1/012090

Simon, Z. B. (2018). The story of humanity and the challenge of posthumanity History of the Human Sciences ( 2018 ), (July). https://doi.org/10.1177/0952695118779519

Smith, B. R., Kistruck, G. M., \& Cannatelli, B. (2016). The Impact of Moral Intensity and Desire for Control on Scaling Decisions in Social Entrepreneurship. Journal of Business Ethics, 133(4). https://doi.org/10.1007/s10551-014-2447-6

Stanley, S. (2018). Predictors of empathy in women social workers. https://doi.org/10.1177/ 1468017318794280

Stoffers, J., Gunawan, A., \& Kleefstra, A. (2018). Social Entrepreneurship, An International Perspective. Open Journal of Social Sciences, 06(10), 342-356. https://doi.org/10.4236/ jss.2018.610002

Strauss\& Glaser. (2009). The Discovery of Grounded Theory, Strategies for Qualitative Research (Seventh pa). New Brunswick (USA) and London (UK): Aldine Transaction

Sun, S. (2018). From Defensive Altruism to Pathological Altruism. SAGE Open, 8(2). https://doi.org/10.1177/2158244018782585

Tang, Y., Moro, A., Sozzo, S., \& Li, Z. (2019). Modelling trust evolution within small business lending relationships, (January). https://doi.org/10.1007/978-3-319-93351-1

Tiwari, H. (2018). Exploring Contribution of Spiritual and Emotional Intelligences ( SI \& EI ) of young Management Graduates to responsible Business Leadership, (January 2015). https://doi.org/10.13140/RG.2.2.31052.67200

Venturing, B. (2018). Journal of Business Venturing, 33(June), 551-565. https://doi.org/10.1016/ j.jbusvent.2018.06.007

Zahra, S. A., \& Wright, M. (2016). Understanding the Social Role of Entrepreneurship. Journal of Management Studies. https://doi.org/10.1111/joms.12149 